Eskişehir Osmangazi Üniversitesi

Sosyal Bilimler Dergisi

Nisan 2019, 20 (Özel Sayı), sayfa aralığı

DOI: 10.17494/ogusbd.553783

\title{
Bütünleştirilmiş Anlaşma Halkaları ve TGA Yönteminin Çözünürlüğe Etki Eden Faktörler Konusundaki Kavram- sal Anlamaya Etkisi
}

\author{
Pınar RUSÇUKLU, Zehra ÖZDiLEK*
} Bütünleştirilmiş Anlaşma Halkaları ve TGA Yönteminin
'Çözünürlüğe Etki Eden Faktörler' Konusundaki Kavram-
sal Anlamaya Etkisi

Özet

Bu çalışmanın amacı "Çözünürlüğe Etki Eden Faktörler" konusunun Tahmin-Gözle-Açıla (TGA) ve anlaşma halkaları yöntemi ile işlenmesi ile öğrencilerin kavramsal anlama düzeylerinin gelişimine etkisini ortaya çıkarmaktır. Çalışmanın başında, "Çözünürlüğe etki eden faktörler” konusuna uygun hazırlanan planlı biçimlendirici değerlendirme sorusu ile öğrencilerin kavram yanılgıları tespit edilmiştir. Çalışmada ayrıca uygulama sonrasında öğrencilerin bu yöntem hakkındaki görüşleri değerlendirilmiştir. Bu çaıışma, uygulama odaklı bir eylem araştırması olup, 12. sınıfta öğrenim gören 23 öğrenci ile toplam 4 ders saatinde yürütülmüştür. Uygulama sonrasında öğrencilere planlı biçimlendirme sorusu tekrar uygulanmış ve ayrıca öğrencilerle görüşmeler yapılmıştır. İki aşamadan oluşan planlı biçimlendirici sorunun analizi yine iki aşamalı olarak yapılmıştır. Sonuç olarak bu yöntem akılda kalıcı, ilgi çekici olması ve dersin öğrenilmesini kolaylaştırması bakımından etkili olmuştur.

Anahtar Kelimeler: Anlaşma Halkaları Yöntemi, Biçimlendirici Değerlendirme, Çözünürlük, TGA, Kimya Eğitimi
The Effect of Integrated Agreement Circles and POE Methods on Conceptual Understanding on Factors of affecting the Solubility

Abstract

The aim of this study is to determine the effect of "The Factors Affecting The Solubility" on the development of conceptual understanding levels of students by using integrated Predict-Observe-Explain (POE) and agreement circles method. At the beginning of the study, students' misconceptions were determined by an planned formative assessment question which was prepared in accordance with the factors affecting the solubility. Students' opinions about this method were also evaluated in this study. This study was an application-oriented action research and was conducted with 23 students at the 12th grade in a total of 4 courses.. After the study, the students were applied the planned formattive assessment question again and interviews were also conducted with students. The analysis of the question, which consisted of two phases, was carried out in two stages. As a result, this method has been effective in terms of being memorable, engaging and facilitating the learning of the course.

Key Words: Agreement Circles Method, Formative Evaluation, Solubility, POE, Chemistry Education

\section{Giriş}

Bilim ve teknolojide yaşanan hızlı değişim, bireyin ve toplumun değişen ihtiyaçları, öğrenme öğretme teori ve yaklaşımlarındaki yenilik ve gelişmeler bireylerden beklenen rolleri de doğrudan etkilemiştir. Bu değişim bilgiyi üreten, hayatta işlevsel olarak kullanabilen, problem çözebilen, eleştirel

*Pınar RUSÇUKLU, Öğrt., Bursa Uludağ Üniversitesi, Eğitim Bilimleri Enstitüsü, pinar_1988__@hotmail.com , ORCID ID orcid.org / 0000-0002-7227-4460 Zehra ÖZDiLEK, Doç. Dr., Bursa Uludağ Üniversitesi, Eğitim Fakültesi, zozdilek@uludag.edu.tr, ORCID ID orcid.org / 0000-0002-0441-1048 
düşünen, girişimci, kararlı, iletişim becerilerine sahip, empati yapabilen, topluma ve kültüre katkı sağlayan vb. niteliklerdeki bir bireyi tanımlamaktadır. Bu nitelik dokusuna sahip bireylerin yetişmesine hizmet edecek öğretim programları salt bilgi aktaran bir yapıdan ziyade bireysel farklılıkları dikkate alan, değer ve beceri kazandırma hedefli, sade ve anlaşılır bir yapıda hazırlanmıştır (MEB, 2018). Bu amaç doğrultusunda öğrencileri muhakeme etmeye ve eleştirel düşünmeye sevk edecek sorularla bilgilerinin ölçülmesi ve onların araştıran, sorgulayan, eleştirel düşünen, tartışan, muhakeme eden ve problem çözen bireyler olarak yetişmelerini sağlayacak yöntemler ile değerlendirilmeleri gerekmektedir.

Değerlendirmede asıl olan öğrencinin neleri anlayıp neleri eksik bildiği, ne tür kavram yanılgllarına düştüklerini belirlemeye nicel ve nitel çözümlemeler getirmektir (Bulunuz ve Bulunuz, 2016). İlgili araştırmalar incelendiğinde ülkemizde biçimlendirici değerlendirmenin tanılayıcı ve düzey belirleyici değerlendirmelere nazaran daha az bilindiği söylenebilir. Biçimlendirici değerlendirme not verme amacı gütmeyen, öğrencilerin ders sırasında kavramsal anlamasını destekleyen öğretim ile kaynaşık hem bir değerlendirme hem de bir öğretim yöntemidir (Bulunuz ve Bulunuz, 2013; Keeley, 2008).

Ülkemizde ve dünyada biçimlendirici değerlendirmenin ne olduğu üzerine birçok çalışma mevcuttur. (Bell ve Cowie, 2000; Bennett, 2011; Black, 1996; Boston, 2002; Fluckiger, Tixier, Pasco \& Danielson, 2010; Stull, Varnum, Ducette, Schiller \& Bernacki, 2011). Örneğin Bell \& Cowie (2000) yaptıkları çalışmada, biçimlendirici değerlendirmenin cevap verme, profesyonel bilgi ve tecrübeleri kullanarak öğretme ve öğrenme sürecinin ayrılmaz bir parçası olduğunu vurgulamıştır. Boston (2002) yaptığı çalışmada, biçimlendirici değerlendirmenin öğretim süresince öğretmenlere ve öğrencilere geri bildirim sağladığını vurgulamıştır. Fluckiger vd. (2010) yaptıkları çalışmada, bu yaklaşımın gerçekleşmesi gereken değişiklikler için zamanında geribildirim verdiğini, öğrenciler için iskele sağladığını, hem öğretim yöntemi ve en önemlisi de öğrencileri değerlendirmede kullanılabileceğini ve verimli bir sınıf iklimine katkıda bulunduğunu dile getirmiştir. Geribildirimin, öğretme ve öğrenme sürecini geliştirmek için kilit bir strateji olduğunu vurgulamıştır. Stull vd. (2011) yaptıkları çalışmada, biçimlendirici değerlendirmeyi ele almış ve nasıl olduğunun yollarını tartışmışlardır.

Öğretmenlerin biçimlendirici değerlendirme yaklaşımını nasıl uyguladıklarını ortaya koyan az sayıda çalışma mevcuttur. (Cowie \& Bell,1999; Furtak, Ruiz Primo, Shemwell, Ayala, Brandon, Shavelson \& Yin, 2008) Örneğin Furtak vd. (2008) yaptıkları çalışmada, deney grubundaki öğretmenlerin çoğunun yöntemi tasarlandığı gibi uygulamadıklarını tespit etmişlerdir. Cowie ve Bell (1999) yaptıkları çalışmada, öğretmenlerin planlı ve etkileşimli olmak üzere iki tür biçimlendirici değerlendirme yaptığını göstermektedir. Planlı biçimlendirici değerlendirme, öğretmenlerin değerlendirme bilgisini ortaya çıkardığı ve yorumladığı ve daha sonra harekete geçmesi ile ilgilidir. Etkileşimli biçimlendirici değerlendirme, öğretmenlerin küçük gruplarla birlikte fark etme, tanıma, yanıt verme ve eğilme eğiliminde bulunması ile ilgilidir. Bu iki tür biçimlendirici değerlendirmenin, öğretme ve öğrenme süreçlerinde ayrımaz oldukları ve öğretmenlerin pedagojik bilgilerine nasıl bağımlı olduklarını anlatmaktadırlar. 
İlgili alan araştırması sonucunda ülkemizde biçimlendirme değerlendirmenin ortaokul düzeyinde kütle, ağırlık, atalet, hava direnci, sürtünme kuvveti ve yer çekimi kayması (Bulunuz, Bulunuz ve Peker, 2014), maddenin yapısı ve özellikleri (Bala, 2013), güneş sistemi ve ötesi (Topçu, 2017); lise düzeyinde eylemsizlik (Bulunuz ve Bulunuz, 2016), Isı ve sıcaklık (Bulunuz, Kıryak, Tomaç, Karagöz ve Recepoğlu, 2017), denge ve tork (Bulunuz ve Bulunuz, 2017); üniversite düzeyinde genel kimya (Yalaki, 2010) alanında çalışıldığı tespit edilmiştir. Bu çalışmada 12. Sınıf öğrencilerine "Çözünürlüğe etki eden faktörler" konusu biçimlendirici değerlendirme uygulamaları ile aktarılmıştır.

İlgili alan araştırmasında, "Çözünürlüğe etki eden faktörler" ile ilgili öğrencilerin sahip oldukları kavram yanılgılarını ortaya koyan çalışmalar tespit edilmiştir (Coştu, Ayas, Açıkkar ve Çalık, 2007; Tezcan ve Bilgin, 2004). Bu çalışmalarda öğrencilerin çözünme ve erimenin aynı olaylar olduğu, çözünmenin çözünen maddenin gözden kaybolması olduğu, iki sıvının birbiri içinde çözünmemesinin yoğunluklarının farklı olmasından kaynaklandığı, bazı sıvıların birbiri içinde çözünmemesinin nedeninin tanecikler arasında yer bulamamasından kaynaklandığı, çözünme olayında çözücü ve çözünenin birleşerek bileşik oluşturduğu, suyun çok iyi bir çözücü olup her şeyi çözebileceği, suyun her zaman çözücü olduğu, çözünen maddenin katı olması gerektiği, çözünen madde çözündüğünde kütlesinde azalma olması gerektiği, çözücü miktarının içinde çözünen maddenin çözünmesiyle artacağı, çözeltinin kütlesinin çözücü kütlesine eşit olduğu, çözünürlüğün katı bir maddenin sıvı bir madde içerisinde çözünmesi olduğu, sıcaklık arttııldığında bütün katıların çözünürlüğünün artacağı, çözünen tanecikleri yeterince küçük olmadığında çözünmenin olmayacağı (Tezcan ve Bilgin, 2004); çözücü ve çözünen miktarının çözünürlüğü etkilediği, katı maddenin büyüklüğünün çözünürlüğü etkilediği, sıcaklığın çözünürlüğü etkilemediği, doygun bir çözeltiye çözücü ilavesi ile çözeltinin yoğunluğunun artacağı, doymamış bir çözelti içerisine çözünen ilavesi ile çözücünün kütlesinin artacağı (Coştu, Ayas, Açıkkar ve Çalık, 2007) şeklinde görüşlere sahip oldukları ortaya çıkarılmıştır. Bourgeois, Dutura, Mccrohan, Riviera, Smith, Souza ve Pariser (1986) yaptıkları çalışmada çözünürlük konusunun öğrencilerin ön bilgileri tespit edilip ardından deneyler yapılarak daha iyi öğretilebileceğini savunmuşlardır. Bu çalışmada da öğrencilerin ön bilgileri tespit edilerek kullanılacak yöntemler anlaşma halkaları (Keeley, 2008, s. 51) ve bir gösteri deneyi olan tahmin et-gözle-açıkla (Keeley, 2008, s. 153) kitabından alınmıştır. Anlaşma halkaları yönteminde öğrenciler sınıfın ortasında bir halka oluştururlar. Öğretmen, öğrencilere bir ifade okur ve bu görüşe katılan öğrencilerin halkanın içerisine girmesini katılmayanların ise halkanın dışına çıkmasını ister. Daha sonra öğrencilerin fikirlerini dinler. Fikirler dinlenirken öğrenciler yerlerini değiştirebilirler. Bu doğrultuda fikirlerini savunabilirler. Bütün öğrenciler dinlendikten sonra öğretmen yanlış anlaşılan kavramları anlaşıır kılar. Tahmin et-gözleaçıkla yönteminin uygulanmasında öğrenciler tahminlerini kendilerine dağıtılan çalışma yapraklarına yazarlar. Tahmin yürütme öğrencide motivasyonu arttıır ve gözleme odaklanmayı kolaylaştırır (White \& Gunstone, 1992). Gözlem aşamasında gösteri deneyi ile gözlem yapmaları sağlanır. Yapılan tahmin ile gözlem arasındaki fark ve çelişkiler öğrenmeyi ilerletebilir (White \& Gunstone, 1992). Açıklama aşamasında yaptıkları deney sonucunda elde ettiklerini bilimsel verilere dayalı olarak açıklarlar. Yaptığı gözlem ile tahmini arasındaki benzerlik ve farklııkları gören öğrenci, çelişkili durumları gidermek için açıklamalar yapar. Öğretmen bu süreçte doğrudan açıklama yapmaz, öğrencilere kılavuzluk ederek yorumlar getirmelerine teşvik eder. 
PInar RUSÇUKLU | Zehra ÖZDILEK

Bu çalışmada anlaşma halkaları ve TGA yöntemleri, öğrencilerinin anlamlı öğrenmelerine katkı sağlayacağı düşünülerek kullanılmıştır.

\subsection{Araştırmanın Amacı}

Bu araştırmanın üç amacı vardır. Birincisi; planlı biçimlendirici değerlendirme uygulamaları ile 12. sınıf öğrencilerinin "Çözünürlüğe etki eden faktörler" konusunda sahip oldukları kavram yanılgılarını tespit etmek, ikincisi; konunun Tahmin et- gözle-açıkla ve anlaşma halkaları yöntemi ile işlenmesi ile öğrencilerin kavramsal anlama düzeylerinin gelişimine etkisini incelemek, üçüncüsü ise uygulamaya katılan öğrencilerin yöntem hakkındaki görüşlerini değerlendirmektir.

\subsection{Araştırmanın Problemi}

Bu çalışmanın alt problemleri; (1) “Çözünürlüğe etki eden faktörler” konusunda 12. sınıf öğrencilerinin sahip oldukları kavram yanılgıları nelerdir?, (2) TGA ve anlaşma halkaları yöntemine dayalı öğretim uygulamasının 12. sınıf öğrencilerinin "Çözünürlüğe etki eden faktörler" konusundaki kavramsal anlama düzeylerinin gelişimine etkisi nedir? ve (3) Öğrencilerin TGA ve anlaşma halkaları yönteminin "Çözünürlüğe etki eden faktörler" konusunun öğretimindeki etkililiği ve kullanılabilirliği ile ilgili görüşleri nelerdir? şeklinde belirlenmiştir.

\section{Yöntem}

\subsection{Araştırmanın Modeli}

Bu çalışma, uygulama odaklı bir eylem araştırmasıdır. Araştırmanın amacı 12. sınıf öğrencilerinin "Çözünürlüğe etki eden faktörler" konusunda sahip oldukları kavram yanılgılarını planlı biçimlendirici değerlendirme sorusu ile ortaya çıkarmak ve elde edilen verilere dayalı hazırlanan ders planı ile öğrencilerin kavramsal anlama düzeylerinin gelişimini desteklemektir. Çalışmada karma araştırma yaklaşımlarından biri olan eylem araştırması yaklaşımı kullanılmıştır (Cooper-Twamley, 2009; Yuladur ve Doğan, 2009). Bu çalışma okulda yapılan öğretim uygulamalarını geliştirmeye yönelik olması nedeniyle "uygulama odaklı eylem araştırması" olarak da adlandırımaktadır (Yıldırım ve Şimşek, 2013). Bu kapsamda MEB'de deneyimi olan kimya öğretmeni olarak görev yapan doktora öğrencisi ile üniversitede fen bilgisi alanında görevli araştırmacl; problem durumunu, problemlerin oluşmasına sebep olan etmenleri ve müdahale yollarını bir araya gelerek saptamışlardır. Eylem araştırmalarının esnek bir yapıya sahip olması ve öğretmen ve araştırmacıların sürekli etkileşim halinde olması uygulama sürecinde araştırmanın seyrini değiştirilebilmektedir. Çalışma üç temel aşamada yürütülmüştür. Birinci aşamada Kimya dersi 11. sınıf planları doğrultusunda "Çözünürlüğe etki eden faktörler" konusu ile ilgili biçimlendirici yoklama sorusu geliştirilmiştir. Daha sonra bu yoklama sorusu öğrencilere uygulanmış ve elde edilen verilerden yola çıkılarak araştırma problemleri belirlenmiştir. İkinci aşamada problemlerin çözümüne yönelik ders planı geliştirilmiş ve TGA yönteminin ardından anlaşma halkaları uygulanmıştır. Son aşamada ise uygulamalardan elde edilen veriler analiz edilip sonuçlar yorumlanmıştır. 


\subsection{Araştırmanın Çalışma Grubu}

Çalışma Bursa ilinde bulunan bir Anadolu Lisesi'nde 12. sınıfta öğrenim gören 12'si kız (\%52.17) ve 11 'i erkek (\%47.83) olmak üzere toplam 23 öğrenci ile yürütülmüştür. Çalışma, öğrencilerin kimya dersinde ve 4 ders saati olarak uygulanmıştır.

\subsection{Araştırmanın Veri Toplama Araçları}

Çalışmada 2 adet veri toplama aracı kullanıımıştır. Bunlar uygulamanın başında ve sonunda öğrencilere uygulanan planlı biçimlendirici değerlendirme soruları ile çalışma sonunda öğrenciler ile gerçekleştirilen yarı yapılandırımış görüşmedir. Yarı yapılandırılmış görüşme soruları; (1) Anlaşma halkalarını derste uyguladıktan sonra bu çalışma sizde arkadaşlarınız ile herhangi bir fizik, kimya ya da biyoloji konusunu tartışma hevesi uyandırdı mı? (2) Anlaşma halkaları yöntemi ilginizi çekti mi? Diğer kimya derslerinde ya da farklı disiplinlerde (fizik, biyoloji vs.) uygulanmasını ister misiniz? (3) Anlaşma halkaları yöntemini bu haliyle yeterli buluyor musunuz? Yeterli bulmuyor iseniz geliştirilmesi için önerileriniz nelerdir? (4) TGA hakkındaki görüşleriniz nelerdir? Değerlendirme çalışması için "planlı biçimlendirici değerlendirme soruları" geliştirilmiştir (EK 1). Bu sorular öğrencilere not verme amacı gütmeyen, öğrencilerde mevcut ise alternatif kavramları tespit etmek ve bunları gidermek aynı zamanda kavramsal anlama düzeylerinin gelişimine etkisine katkıda bulunmak için geliştirilen bir ölçme aracıdır.

\subsection{Verilerin Toplanması}

İlk olarak 11. sınıf Kimya öğretim programı incelenerek "Çözünürlüğe etki eden faktörler" konusuyla ilgili kazanımlar tespit edilmiştir. Bu kazanımlar doğrultusunda, planlanmış biçimlendirici değerlendirme sorusu öğrencilerin sahip oldukları kavram yanılgılarını tespit etmek için ön test şeklinde uygulanmıştır. Yoklama sorusunun uygulanabilirliği hakkında fikir sahibi olmak amacıyla Bursa ili Osmangazi ilç̧e merkezindeki bir liseden 28 onbirinci sınıf öğrencisi ile pilot çalışmalar yürütülmüştür. Çalışmada kullanılan değerlendirme sorusu çözünürlüğe etki eden faktörler ile ilgilidir. İki aşamalı olarak tasarlanan değerlendirme sorusunun birinci aşaması çoktan seçmeli, ikinci aşaması ise açık uçludur. Birinci aşamasında verilen seçenekler daha önce farklı düzeylerdeki öğrencilerle yapılan çaıışmalarda tespit edilen alternatif kavramlar, yaygın olarak kullanılan eksik ve yanlış bilgilerden oluşmaktadır. İkinci aşamada ise öğrencilerden ilk aşamada yaptıkları seçimin gerekçelerini açıklamaları istenmiştir. "Çözünürlüğe etki eden faktörler" konusunda öğretim uygulanmaya başlamadan bir hafta önce, uyarlanan biçimlendirici değerlendirme sorusu öğrencilere ön test olarak uygulanmıştır. Araştırmacılar tarafından öğrencilerin sorulara verdikleri cevaplar analiz edilerek değerlendirme soruları için ders planı ve etkinlik tasarlanmıştır (EK2). Son testte biçimlendirici değerlendirme soruları tekrar kullanılmıştır. Son test, uygulamanın bitiminden iki hafta sonra uygulanmıştır. Ayrıca, öğrencilerle uygulanan yöntem hakkındaki görüşlerini almak için yarı yapılandırılmış görüşmeler 23 öğrenci ile gerçekleştirilmiştir.

\subsection{Verilerin Analizi}


Ön test ve son testte kullanılan iki aşamalı soruların analizi için Karataş, Köse ve Coştu (2003) tarafından geliştirilen değerlendirme ölçütleri kullanılmıştır. İlk olarak öğrencilerin değerlendirme sorularının çoktan seçmeli kısmına verdikleri cevaplar incelenerek doğru cevap / yanlış cevap olarak sınıflandırımıştır. Soruların açık uçlu kısımlarının değerlendirilmesinde ise "doğru gerekçe, kısmen doğru gerekçe, yanlış gerekçe ve boş" olmak üzere dört ölçüt dikkate alınarak cevaplar sınıflandırımış ve her iki aşamadan elde edilen veriler birleştirilerek değerlendirme tamamlanmıştır. íki aşamalı testin değerlendirilmesinde kullanılan değerlendirme ölçütü Tablo 1'de verilmiştir.

Tablo 1. İki Aşamalı Testin Değerlendirilmesinde Kullanılan Değerlendirme Ölçütü

\begin{tabular}{cllc}
\hline \hline Anlama düzeyleri & \multicolumn{1}{c}{ Açıklama } & \multicolumn{1}{c}{ Değerlendirme ölçütleri } & Puan \\
\hline Doğru gerekçe & $\begin{array}{l}\text { Geçerliliği olan gerekçenin } \\
\text { bütün yönlerini içeren ce- } \\
\text { vaplar }\end{array}$ & Doğru cevap-doğru gerekçe & 3 \\
\hline Kısmen doğru gerekçe & $\begin{array}{l}\text { Geçerli gerekçenin bütün } \\
\text { yönlerini içermeyen cevap- } \\
\text { lar }\end{array}$ & $\begin{array}{l}\text { Doğru cevap-kısmen doğru ge- } \\
\text { rekçe }\end{array}$ & 2 \\
\hline Yanlış gerekçe & $\begin{array}{l}\text { Doğru olmayan bilgiler içe- } \\
\text { ren cevaplar }\end{array}$ & $\begin{array}{l}\text { Yanlış cevap-kısmen doğru ge- } \\
\text { rekçe Doğru cevap-yanlış ge- } \\
\text { rekçe }\end{array}$ & 2 \\
\hline Boş & $\begin{array}{l}\text { ilgisiz, açık olmayan cevap } \\
\text { verme veya boş bırakma }\end{array}$ & Yanlıs cevap-yanlış gerekçe & 0 \\
\hline
\end{tabular}

İki aşamalı bir test olan biçimlendirici değerlendirme sorusunun puanlanması Tablo 2'de görüldüğü gibi yapılmıştır. Tabloya göre öğrenci çoktan seçmeli aşamada doğru cevap verip içerik aşamasında yanlış cevap verecek olursa 1 puan, ancak yanlış cevap verip kısmen doğru gerekçe sunarsa 2 puan verilir. Uygulanan iki aşamalı teste verilen yanıtların sınıflandırılmasında verilen adlandırma ise şu şekilde yapılmıştır: Doğru cevap-doğru gerekçe: Tam Kavrama (TK), Doğru cevap-kısmen doğru gerekçe / Yanlış cevap-kısmen doğru gerekçe: Kısmen kavrama (KK), Doğru cevap-yanlış gerekçe: Spesifik Kavram Yanılgısı (SKY), Yanlış cevap-yanlış gerekçe: Hiç anlamama (HA)

Şahin ve Çepni (2011) tarafından iki aşamalı testlerin iki aşamasından elde edilen verilerin birlikte analiz edilmesinin uygun olduğu belirtilmiştir. Öğrencilerin verdiği cevaplar tam kavrama, kısmen kavrama, spesifik kavram yanılgısı ve hiç anlamama şeklinde kategorilere ayrılarak tablolaştırılmıştır. Elde edilen veriler doğrultusunda yorum yapılmıştır. Görüşmeden elde edilen veriler içerik analizine tabi tutulmuştur.

\section{Bulgular ve Yorum}

\section{1. Öğrencilerin Planlı Biçimlendirici Sorularından Uygulama Öncesi ve Sonrası Elde Ettikleri}

\section{Bulgular}


Bu bölümde öğrencilere uygulanan planlı biçimlendirici değerlendirme sorularından elde edilen bulgular sunulmuştur. Tablo 2'de öğrencilerin uygulama öncesinde planlı biçimlendirme sorularına verdikleri yanıtların yüzde ve frekans değerleri görülmektedir.

Tablo 2. Uygulama Öncesi Biçimlendirme Soruları İçin Öğrenci Cevaplarının Kategorilere Göre Frekans ve \% Değerleri

\begin{tabular}{crrrrrrrrr}
\hline \hline & \multicolumn{2}{c}{ TK } & \multicolumn{2}{c}{ KK } & \multicolumn{3}{c}{$S K Y$} & \multicolumn{3}{c}{$H A$} \\
SORU & $\mathrm{f}$ & $\%$ & $f$ & $\%$ & $f$ & $\%$ & $f$ & $\%$ \\
\hline 1 & 3 & 13,04 & 3 & 13,04 & 17 & 73,91 & 0 & 0 \\
2 & 3 & 13,04 & 1 & 4,35 & 8 & 34,78 & 11 & 47,83 \\
3 & 0 & 0 & 6 & 26,09 & 7 & 30,43 & 10 & 43,48 \\
4 & 0 & 0 & 6 & 26,09 & 7 & 30,43 & 10 & 43,48 \\
5 & 2 & 8,70 & 3 & 13,04 & 17 & 73,91 & 1 & 4,35 \\
6 & 1 & 4,35 & 1 & 4,35 & 14 & 60,87 & 7 & 30,43 \\
7 & 1 & 4,35 & 5 & 21,74 & 12 & 52,17 & 5 & 21,74 \\
8 & 1 & 4,35 & 7 & 30,43 & 5 & 21,74 & 10 & 43,48 \\
\hline
\end{tabular}

TK: Tam Kavrama, KK: Kısmen Kavrama, SKY: Spesifik Kavram Yanılgısı, HA: Hiç Anlamama

Benzer şekilde, öğrencilerin uygulama sonrasında planlı biçimlendirme sorularına verdikleri yanıtların yüzde ve frekans değerleri Tablo 3'te görülmektedir.

Tablo 3. Uygulama Sonrası Biçimlendirme Soruları İçin Öğrenci Cevaplarının Kategorilere Göre Frekans ve \% Değerleri

\begin{tabular}{crrrrrrrrr}
\hline \hline & \multicolumn{2}{c}{ TK } & \multicolumn{2}{c}{ KK } & \multicolumn{2}{c}{$S K Y$} & \multicolumn{3}{c}{$H A$} \\
SORU & $f$ & $\%$ & $f$ & $\%$ & $f$ & $\%$ & $f$ & $\%$ \\
\hline 1 & 1 & 4,35 & 7 & 30,43 & 15 & 65,22 & 0 & 0 \\
2 & 2 & 8,70 & 7 & 30,43 & 11 & 47,83 & 3 & 13,04 \\
3 & 0 & 0 & 9 & 39,13 & 10 & 43,48 & 4 & 17,40 \\
4 & 0 & 0 & 9 & 39,13 & 6 & 26,09 & 8 & 34,78 \\
5 & 3 & 13,04 & 4 & 17,40 & 14 & 60,87 & 2 & 8,70 \\
6 & 3 & 13,04 & 7 & 30,43 & 9 & 39,13 & 4 & 17,40 \\
\hline & 7 & 0 & 0 & 10 & 43,48 & 8 & 34,78 & 5 & 21,74 \\
\hline & 8 & 2 & 8,70 & 9 & 39,13 & 9 & 39,13 & 3 & 13,04 \\
\hline
\end{tabular}

TK: Tam Kavrama, KK: Kısmen Kavrama, SKY: Spesifik Kavram Yanılgısı, HA: Hiç Anlamama 
Tablo 2. incelendiğinde uygulama öncesinde Birinci soru ile ilgili olarak üç öğrencinin soruyu tam kavrama düzeyinde yanıtladığı, 3 öğrencinin kısmen kavrama düzeyinde yanıtladığı; 17 öğrencinin spesifik kavram yanılgısına sahip olduğu tespit edilmiştir. Öğrencilerde tespit edilen kavram yanılgıları aşağıdaki gibidir:

"Çözünürlüğe etki eden faktörler arasında sıcaklık sadece katı ve sıvılara etki eder (Ö1, Ö2, Ö3, Ö4, Ö5, Ö12, Ö13, Ö14, Ö15, Ö16, Ö17, Ö18, Ö20)."

"Sıcaklık artışı katılarda çözünürlügü arttırmaz çözünme hızını arttııı (Ö7; Ö9; Ö10; Ö11)."

Soruyu tam kavrama düzeyinde yanıtlayan öğrenci cevabı aşağıdaki gibidir:

"Katılarda çözünme endotermik olduğundan sıcaklık arttıkça çözünürlükleri artar. Bazı katılar haricinde (Ö6)."

Soruyu kısmen kavrama düzeyinde yanıtlayan bazı öğrenci cevapları aşağıdaki gibidir:

"Sıcak çayda çözünen şeker soğuk çayda çözünen şekerden daha fazladır (Ö19; Ö22)."

Tablo 3. incelendiğinde öğrencilerin uygulama sonrasında birinci soru ile ilgili olarak, 1 öğrencinin soruyu tam kavrama düzeyinde yanıtladığı, 7 öğrencinin kısmen kavrama düzeyinde yanıtladığı; 15 öğrencinin spesifik kavram yanılgısına sahip olduğu tespit edilmiştir.

Uygulama sonrası soruyu tam kavrama düzeyinde yanıtlayan öğrenci cevabı aşağıdaki gibidir: "Katıların çözünürlüğü endotermik olduğundan sıcaklık arttıkça çözünürlükleri artar. Bazı katılar hariç (Ö8)."

Soruyu kısmen kavrama düzeyinde yanıtlayan öğrenci cevapları aşağıdaki gibidir: "Katılarda sıcaklık arttıkça çözünürlük genellikle artar (Ö5, Ö15, Ö16, Ö19, Ö20, Ö22, Ö23)."

Spesifik kavram yanılgısı devam eden öğrenci cevapları aşağıdaki gibidir: "Katılarda sıcaklık arttıkça çözünürlük azalır (Ö1, Ö2, Ö3, Ö4, Ö7, Ö9, Ö10, Ö11, Ö12, Ö13, Ö14, Ö17, Ö18)."

Uygulama öncesinde İkinci soruda, 3 öğrencinin soruyu tam kavrama düzeyinde yanıtladığı, 1 öğrencinin kısmen kavrama düzeyinde yanıtladığı; 8 öğrencinin spesifik kavram yanılgısına sahip olduğu, 11 öğrencinin de soruyu hiç anlamadığı tespit edilmiştir (Tablo 2). Öğrencilerde tespit edilen kavram yanılgıları aşağıdaki gibidir:

"Sıcaklık ile çözünürlük gazlarda doğru orantılı olduğu için sıcaklık arttıkça çözünürlük artar (Ö12; Ö13; Ö15, Ö16, Ö18)."

Soruyu tam kavrama düzeyinde yanıtlayan bazı öğrenci cevapları aşağıdaki gibidir:

“Gazların çözünürlüğü ekzotermik olduğundan sıcaklık arttıkça gazların çözünürlüğü azalır(Ö6; Ö8)."

Soruyu kısmen kavrama düzeyinde yanıtlayan öğrenci cevabı aşağıdaki gibidir: 
"Gazların çözünürlüğü sıcaklık ile ters orantılıdır (Ö17)."

Uygulama sonrasında İkinci soru incelendiğinde 2 öğrencinin soruyu tam kavrama düzeyinde yanıtladığı, 7 öğrencinin kısmen kavrama düzeyinde yanıtladığl; 11 öğrencinin spesifik kavram yanıgısına sahip olduğu, 3 öğrencinin de soruyu hiç anlamadığı tespit edilmiştir (Tablo 3). Uygulama sonrası soruyu tam kavrama düzeyinde yanıtlayan öğrenci cevapları aşağıdaki gibidir: Ö11)."

“Gazların çözünürlüğü ekzotermik olduğundan sıcaklık arttıkça gazların çözünürlüğü azalır(Ö8,

Soruyu kısmen kavrama düzeyinde yanıtlayan öğrenci cevapları aşağıdaki gibidir:

"Gazların sudaki çözünürlüğü sıcaklıkla ters orantılı olduğu için gazlar soğuk suda ılı sudan daha iyi çözünür. Kolada soğuk içiniz yazmasının nedeni budur. (Ö9, Ö16, Ö20, Ö23)."

"Gazların çözünürlüğü sıcaklıkla ters orantılıdır (Ö4, Ö5, Ö17)."

Spesifik kavram yanılgısı devam eden öğrenci cevapları aşă̆ıdaki gibidir:

"Gazların çözünürlüğü sıcaklıkla doğru orantılıdır (Ö12, Ö13, Ö18)."

Tablo 2'de görüldüğü gibi, uygulama öncesinde Üçüncü soruya verilen yanıtlar incelendiğinde, hiçbir öğrencinin soruyu tam kavrama düzeyinde yanıtlayamadığı, 6 öğrencinin kısmen kavrama düzeyinde yanıtladığı; 7 öğrencinin spesifik kavram yanılgısına sahip olduğu, 10 öğrencinin de soruyu hiç anlamadığı tespit edilmiştir. Öğrencilerde tespit edilen kavram yanılgıları aşağıdaki gibidir:

"Kolanın kapağı açılırsa karbondioksit daha fazla çözünür böylece kolanın asitliği de gitmiş olur (Ö17, Ö22)."

Soruyu kısmen kavrama düzeyinde yanıtlayan öğrenci cevapları aşağıdaki gibidir:

"Kolanın kapağı açılınca basınç azalmış olur ve koladaki karbondioksidin çözünürlüğü de azalır (Ö6; Ö15)."

Tablo 3'te uygulama sonrasında Üçüncü soru incelendiğinde hiçbir öğrencinin soruyu tam kavrama düzeyinde yanıtlayamadığı, 9 öğrencinin kısmen kavrama düzeyinde yanıtladığı; 10 öğrencinin spesifik kavram yanılgısına sahip olduğu, 4 öğrencinin de soruyu hiç anlamadığı tespit edilmiştir. Uygulama sonrası soruyu kısmen kavrama düzeyinde yanıtlayan öğrenci cevapları aşağıdaki gibidir:

'Basınç azalırsa gazların sudaki çözünürlüğg̈ azalır. Burada kolanın kapağı açılınca basınç azalmış oluyor ve dışarı $\mathrm{CO}_{2}$ gazı çıkısı olması bunu doğrular (Ö11, Ö19)."

“Basınç azalırsa gazların sudaki çözünürlüğü azalır (Ö8, Ö9, Ö14, Ö17, Ö20, Ö21, Ö23).”

Spesifik kavram yanılgısı devam eden öğrenci cevapları aşağıdaki gibidir:

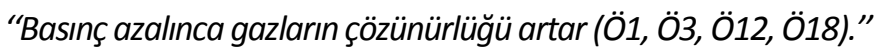


Uygulama öncesinde Dördüncü soru incelendiğinde hiçbir öğrencinin soruyu tam kavrama düzeyinde yanıtlayamadığı, 6 öğrencinin kısmen kavrama düzeyinde yanıtladığı; 7 öğrencinin spesifik kavram yanılgısına sahip olduğu, 10 öğrencinin de soruyu hiç anlamadığı tespit edilmiştir (Tablo 2). Öğrencilerde tespit edilen kavram yanılgıları aşağıdaki gibidir:

"Basınç arttıkça katı ve sıvıların çözünürlüğü $\operatorname{artar}(0 ̈ 7,0 ̈ 9,0 ̈ 22) . "$

Soruyu kısmen kavrama düzeyinde yanıtlayan öğrenci cevabı aşağıdaki gibidir:

"Basınç arttıılarak kola içinde çözünen şeker miktarı arttıılamaz çünkü şeker katıdır ve katılardaki çözünürlüğe basıncın pek etkisi yoktur (Ö4)."

Uygulama sonrasında Dördüncü soru incelendiğinde hiçbir öğrencinin soruyu tam kavrama düzeyinde yanıtlayamadığı, 9 öğrencinin kısmen kavrama düzeyinde yanıtladığı; 6 öğrencinin spesifik kavram yanılgısına sahip olduğu, 8 öğrencinin de soruyu hiç anlamadığı tespit edilmiştir (Tablo 3). Uygulama sonrası soruyu kısmen kavrama düzeyinde yanıtlayan öğrenci cevapları aşağıdaki gibidir:

"Derste yapmıştık. Basınç katı ve sıvıların çözünürlüğüne pek etki etmiyordu. Basınç gazların üzerine etki eder( Ö4, Ö6, Ö8, Ö9,Ö16, Ö17, Ö20, Ö21, Ö23)."

Spesifik kavram yanılgısı devam eden öğrenci cevabı aşağıdaki gibidir:

"Kola zaten basınç arttıılarak $\mathrm{CO}_{2}$ gazı depolanmıştır. Bunu şeker için de yapabiliriz (Ö18)."

Uygulama öncesinde Beşinci soru incelendiğinde 2 öğrencinin soruyu tam kavrama düzeyinde yanıtladığı, 3 öğrencinin kısmen kavrama düzeyinde yanıtladığı; 17 öğrencinin spesifik kavram yanılgısına sahip olduğu, 1 öğrencinin de soruyu hiç anlamadığı tespit edilmiştir (Tablo 2). Öğrencilerde tespit edilen kavram yanılgıları aşağıdaki gibidir:

"Çay ne kadar sıcak olursa şeker o kadar çabuk erir (Ö10)."

Soruyu tam kavrama düzeyinde yanıtlayan öğrenci cevapları aşağıdaki gibidir: "Şekerin suda çözünmesi endotermik olduğundan sıcaklık arttıkça şekerin suda çözünürlüğü artar (Ö6, Ö8)."

Soruyu kısmen kavrama düzeyinde yanıtlayan öğrenci cevabı aşağıdaki gibidir:

"Katıların çözünürlüğü sıcaklıkla doğru orantılı olarak değişir (Ö21)."

Uygulama sonrasında Beşinci soru incelendiğinde 3 öğrencinin soruyu tam kavrama düzeyinde yanıtladığı, 4 öğrencinin kısmen kavrama düzeyinde yanıtladığl; 14 öğrencinin spesifik kavram yanılgısına sahip olduğu, 2 öğrencinin de soruyu hiç anlamadığı tespit edilmiştir (Tablo 3). Uygulama sonrası soruyu tam kavrama düzeyinde yanıtlayan öğrenci cevapları aşağıdaki gibidir:

"Şekerin suda çözünmesi endotermik olduğundan sıcaklık arttıkça şekerin suda çözünürlüğü artar. (Ö6, Ö8, Ö11)." 
Soruyu kısmen kavrama düzeyinde yanıtlayan öğrenci cevapları aşağıdaki gibidir:

"Sıcaklık arttıkça katıların sudaki çözünürlüğü genellikle artar (Ö16, Ö20, Ö21, Ö23)."

Spesifik kavram yanılgısı devam eden öğrenci cevapları aşă̆ıdaki gibidir:

“Sıcaklık arttıkça katıların çözünürlüğü azalır (Ö1, Ö2, Ö3, Ö4, Ö5, Ö9, Ö10, Ö12, Ö14, Ö15).”

"Sıcaklık arttıkça bütün katıların çözünürlüğü $\operatorname{artar}(O ̈ 17$, Ö22)."

Tablo 2'de verilen uygulama öncesinde Altıncı soru incelendiğinde 1 öğrencinin soruyu tam kavrama düzeyinde yanıtladığı, 1 öğrencinin kısmen kavrama düzeyinde yanıtladığı; 14 öğrencinin spesifik kavram yanılgısına sahip olduğu, 7 öğrencinin de soruyu hiç anlamadığı tespit edilmiştir. Öğrencilerde tespit edilen kavram yanılgıları aşă̆ıdaki gibidir:

"Gazların çözünürlüğü endotermiktir (Ö8)."

Soruyu tam kavrama düzeyinde yanıtlayan öğrenci cevabı aşağıdaki gibidir:

"Gazların sudaki çözünürlüğü ekzotermiktir. Bu yüzden $\mathrm{CO}_{2}$ 'in sudaki çözünürlüğü sıcaklık arttıkça azalır. (Ö6)."

Soruyu kısmen kavrama düzeyinde yanıtlayan öğrenci cevabı aşağıdaki gibidir:

"Sıcaklık arttıkça gazların sudaki çözünürlüğü azalır(Ö21)."

Tablo 3'te verilen uygulama sonrasında Altıncı soru incelendiğinde 3 öğrencinin soruyu tam kavrama düzeyinde yanıtladığı, 7 öğrencinin kısmen kavrama düzeyinde yanıtladığı; 9 öğrencinin spesifik kavram yanılgısına sahip olduğu, 4 öğrencinin de soruyu hiç anlamadığı tespit edilmiştir. Uygulama sonrası soruyu tam kavrama düzeyinde yanıtlayan öğrenci cevapları aşağıdaki gibidir:

"Gazların sudaki çözünürlügü ekzotermiktir. Bu yüzden $\mathrm{CO}_{2}{ }^{\prime}$ in sudaki çözünürlüğü sıcaklık arttıkça azalır. (Ö6, Ö8, Ö11)."

Soruyu kısmen kavrama düzeyinde yanıtlayan öğrenci cevapları aşağıdaki gibidir:

“Sıcaklık arttıkça gazların sudaki çözünürlüğü azalır (Ö4, Ö9, Ö14, Ö15, Ö20, Ö21, Ö23).”

Spesifik kavram yanılgısı devam eden öğrenci cevapları aşağıdaki gibidir:

“Sıcaklık arttıkça gazların sudaki çözünürlüğü artar (Ö1, Ö2, Ö3, Ö10, Ö12, Ö13, Ö16, Ö17, Ö18)."

Uygulama öncesinde Yedinci soru incelendiğinde 1 öğrencinin soruyu tam kavrama düzeyinde yanıtladığı, 5 öğrencinin kısmen kavrama düzeyinde yanıtladığl; 12 öğrencinin spesifik kavram yanılgısına sahip olduğu, 5 öğrencinin de soruyu hiç anlamadığı tespit edilmiştir (Tablo 2). Öğrencilerde tespit edilen kavram yanılgıları aşağıdaki gibidir:

"Basıncın düşmesi gazların sıvılardaki çözünürlüğünü arttıır (Ö15, Ö16)." 
Soruyu tam kavrama düzeyinde yanıtlayan öğrenci cevabı aşağıdaki gibidir:

"Gazların çözünürlüğü kısmi basınçlarıyla doğru orantılıdır. Sonuç olarak da basıncın azalması gazların çözünürlügünü azaltır (Ö21)."

Soruyu kısmen kavrama düzeyinde yanıtlayan öğrenci cevabı aşağıdaki gibidir:

“Basınç ile gazların sudaki çözünürlüğü orantıı olduğu için basıncın düşmesi gazların çözünürlüğünü azaltır (Ö6; Ö7; Ö8)."

Uygulama sonrasında Yedinci soru incelendiğinde, hiçbir öğrencinin soruyu tam kavrama düzeyinde yanıtlayamadığı, 10 öğrencinin kısmen kavrama düzeyinde yanıtladığı; 8 öğrencinin spesifik kavram yanılgısına sahip olduğu, 5 öğrencinin de soruyu hiç anlamadığı tespit edilmiştir (Tablo 3). Uygulama sonrası soruyu kısmen kavrama düzeyinde yanıtlayan öğrenci cevapları aşağıdaki gibidir:

"Basınç ile gazların sudaki çözünürlüğü doğru orantılı olduğu için basıncın düşmesi gazların sudaki çözünürlüğünü azaltır (Ö4, Ö6, Ö8, Ö9, Ö14, Ö16, Ö19, Ö20, Ö21, Ö22).”

Spesifik kavram yanılgısı devam eden öğrenci cevapları aşağıdaki gibidir:

“Basınç ile gazların sudaki çözünürlüğü ters orantılıdır (Ö1, Ö2, Ö11, Ö12, Ö18, Ö23).”

Tablo 2' de uygulama öncesinde Sekizinci soru incelendiğinde 1 öğrencinin soruyu tam kavrama düzeyinde yanıtladı̆̆ı, 7 öğrencinin kısmen kavrama düzeyinde yanıtladığı; 5 öğrencinin spesifik kavram yanılgısına sahip olduğu, 10 öğrencinin de soruyu hiç anlamadığı tespit edilmiştir. Öğrencilerde tespit edilen kavram yanılgıları aşağıdaki gibidir:

"Basınç katı ve sıvılarda etkilidir (Ö2; Ö6; Ö11; Ö18; Ö20; Ö23)."

Soruyu tam kavrama düzeyinde yanıtlayan öğrenci cevabı aşağıdaki gibidir:

"Bir katının veya sıvının çözünürlüğüne basınç pek etki etmez. Çünkü katı ve sıvıların hacimlerine basınç uygulayarak değişme olmaz. (Ö21)."

Soruyu kısmen kavrama düzeyinde yanıtlayan öğrenci cevabı aşağıdaki gibidir:

"Katıların çözünürlüğünü sıcaklık etkiler ama katı ve sıvıların çözünürlüğünü basınç pek etkilemez (Ö8)."

Tablo 3'te uygulama sonrasında Sekizinci soru incelendiğinde 2 öğrencinin soruyu tam kavrama düzeyinde yanıtladığı, 9 öğrencinin kısmen kavrama düzeyinde yanıtladığı; 9 öğrencinin spesifik kavram yanılgısına sahip olduğu, 3 öğrencinin de soruyu hiç anlamadığı tespit edilmiştir. Uygulama sonrası soruyu tam kavrama düzeyinde yanıtlayan öğrenci cevabı aşağıdaki gibidir:

"Bir katının veya sıvının çözünürlüğüne basınç pek etki etmez. Çünkü katı ve sıvıların hacimlerine basınç uygulayarak değişme olmaz. (Ö9, Ö19)." 
Soruyu kısmen kavrama düzeyinde yanıtlayan öğrenci cevapları aşağıdaki gibidir:

"Basıncın değişmesi katı ve sıvıların çözünürlüğünü pek etkilemez. Derste yapmıştık. Henry Yasası ile gazları etkiliyordu. (Ö5, Ö6, Ö7, Ö8, Ö16, Ö20, Ö21, Ö22, Ö23)."

Spesifik kavram yanılgısı devam eden öğrenci cevapları aşağıdaki gibidir:

"Basınç gazları da katı ve sıvıları da etkiler (Ö11, Ö18)."

\subsection{Görüşmeden elde edilen bulgular}

Bu bölümde öğrenciler ile yapılan yarı yapılandırılmış görüşmelerden elde edilen veriler sunulmuştur. 12. sınıf öğrencilerinin anlaşma halkalarını derste uyguladıktan sonra bu çalışmanın onlarda arkadaşları ile herhangi bir fizik, kimya ya da biyoloji konusunu tartışma hevesi uyandırıp uyandırmadığını öğrenmek için yöneltilen 'Soru 1' için elde edilen bulgular Tablo 4'te sunulmuştur.

Tablo 4. Öğrencilerin Anlaşma Halkalarını Derste Uyguladıktan Sonra Bu Çalışma Sizde Arkadaşlarınız Ile Herhangi Bir Fizik, Kimya ya da Biyoloji Konusunu Tartışma Hevesi Uyandırdı Mı? Sorusuna Verdiği Cevaplara Ait Kodların Frekans Ve Yüzde Değerleri

\begin{tabular}{lrrr}
\hline \multicolumn{1}{c}{ Kod } & Öărenci & Fre- & Yüzde \\
\hline Arkadaşları ile bazı sorular hakkında tartışma hevesi uyandırması & Ö1, Ö17, Ö19 & 3 & 13,04 \\
Fikir alışverişinde bulunma imkanı tanıması & Ö10, Ö21 & 2 & 8,69 \\
Sorgulayıcı olması & Ö11, Ö22 & 2 & 8,69 \\
Eğlenerek öğrenmeyi sağlaması & Ö10 & 1 & 4,34 \\
Faydalı olması & Ö7 & 1 & 4,34 \\
\hline
\end{tabular}

Tablo 4. incelendiğinde 19 öğrencinin (Ö1, Ö3, Ö5, Ö6, Ö7, Ö8, Ö9, Ö10, Ö11, Ö13, Ö15, Ö16, Ö17, Ö18, Ö19, Ö20, Ö21, Ö22, Ö23) anlaşma halkaları yöntemi derste uygulandıktan sonra bu çaıışmanın onlarda arkadaşları ile herhangi bir fizik, kimya ya da biyoloji konusunu tartışma hevesi uyandırdığı tespit edilmiştir. Bu yöndeki bazı öğrenci görüşleri aşağıdaki gibidir:

"Evet uyandırdı. Anlaşma halkaları tartışma için mantıklı ve yararlı bir yöntem (Ö7)."

"Evet. Tartıştıkça hem fikir alışverişinde bulunuyoruz hem eğleniyoruz hem de yeni görüşler yakalama fırsatı buluyoruz (Ö10)."

4 öğrencinin (Ö2, Ö4, Ö12, Ö14) anlaşma halkaları yöntemi derste uygulandıktan sonra bu çaış̧manın onlarda arkadaşları ile herhangi bir fizik, kimya ya da biyoloji konusunu tartışma hevesi uyandırmadığı tespit edilmiştir. Bu yöndeki bir öğrenci görüşü aşağıdaki gibidir:

"Hayır uyandırmadı çünkü verim alamadım (Ö4)."

Anlaşma halkaları yönteminin 12. sınıf öğrencilerinin ilgisini çekip çekmediğini öğrenmek ve diğer kimya derslerinde ya da farklı disiplinlerde (fizik, biyoloji vs.) uygulanmasını isteyip istemediklerini tespit etmek amacıyla yöneltilen 'Soru 2' için elde edilen bulgular Tablo 5'te sunulmuştur. 
Tablo 5. Öğrencilerin Anlaşma Halkaları Yöntemi İlginizi Çekti Mi? Diğer Kimya Derslerinde ya da Farklı Disiplinlerde (Fizik, Biyoloji Vs.) Uygulanmasını İster Misiniz? Sorusuna Verdiği Cevaplara Ait Kodların Frekans Ve Yüzde Değerleri

\begin{tabular}{lrrr}
\hline \hline Kod & Öğrenci & Frekans & Yüzde \\
\hline Güzel olması & Ö2, Ö5, Ö17, Ö19 & 4 & 17,39 \\
Öğretici olması & Ö5, Ö7, Ö13 & 3 & 13,04 \\
Fizikte kullanılmasının iyi olabileceği & Ö3, Ö14, Ö18 & 3 & 13,04 \\
Faydalı olması & Ö17, Ö21 & 2 & 8,69 \\
Eğlenceli olması & Ö4 & 1 & 4,34 \\
Monotonluktan çıkarması & Ö2 & 1 & 4,34 \\
Konuşma kabiliyetini geliştirmesi & Ö15 & 1 & 4,34 \\
Biyoloji ve felsefede kullanıımasının iyi olabileceği & Ö22 & 1 & 4,34 \\
Fikir alışverişinde bulunma imkanı sağlaması & Ö15 & 1 & 4,34 \\
Kendini rahat ifade edebilme imkanı sağlaması & Ö20 & 1 & 4,34 \\
\hline
\end{tabular}

Tablo 5. incelendiğinde tüm öğrencilerin anlaşma halkaları yönteminin ilgilerini çektiği, diğer kimya derslerinde ya da farklı disiplinlerde uygulanmasını istedikleri tespit edilmiştir. Bu yöndeki bazı öğrenci görüşleri aşağıdaki gibidir:

"Fizikte uygulanmasını isterim (Ö3)."

"Anlaşma halkaları yöntemi güzel ve öğretici bir yöntem. Diğer derslerde de uygulanmasını isterim (Ö5)."

"Fizik, kimya ve biyoloji derslerinde her konu sonunda yapılırsa konu ve kavramlar daha iyi kavranabilir. Öğretici. Bence uygulanmalı fakat bunu 9. Sınıftan başlayarak yapmalıydık (Ö13)."

“ilgimi çekti. Özellikle fizik dersi için çok yararlı olacağını düşünüyorum (Ö14).”

8 öğrenci (Ö1, Ö6, Ö8, Ö9, Ö10, Ö11, Ö16, Ö23) ise soruya olumlu yanıt vermiş ancak nedenini açıklamamıştır.

Öğrencilerin anlaşma halkaları yöntemini bu haliyle yeterli bulup bulmadıklarını, yeterli bulmuyor iseler geliştirilmesi için önerilerinin neler olduğunu tespit etmek amacıyla yöneltilen 'Soru 3' için elde edilen bulgular Tablo 6 'da sunulmuştur.

Tablo 6. Öğrencilerin Anlaşma Halkaları Yöntemini Bu Haliyle Yeterli Buluyor Musunuz? Yeterli Bulmuyor İseniz Geliştirilmesi İçin Önerileriniz Nelerdir? Sorusuna Verdiği Cevaplara Ait Kategori Ve Kodların Frekans Ve Yüzde Değerleri 


\begin{tabular}{|c|c|c|c|c|}
\hline Kategori & Kod & Öğrenci & Frekans & Yüzde \\
\hline \multirow[t]{8}{*}{ Öneriler } & tutulabilir. & Ö2, Ö5, Ö9 & 3 & 13,04 \\
\hline & Katılımı arttırıcı çözüm üretilmeli. & Ö15, Ö18, Ö23 & 3 & 13,04 \\
\hline & Video ile desteklenebilir. & Ö3 & 1 & 4,34 \\
\hline & Rekabet ortamı oluşturulabilir. & Ö9 & 1 & 4,34 \\
\hline & Sorular daha anlaşılır olmalı. & Ö14 & 1 & 4,34 \\
\hline & Sorular fotokopi ile dağıtılabilir. & Ö1 & 1 & 4,34 \\
\hline & $\begin{array}{l}\text { Konu, halkadan sonra özet şeklinde } \\
\text { toparlanmalı. }\end{array}$ & Ö17 & 1 & 4,34 \\
\hline & Halkasız tartışma ortamı yaratılmalı. & Ö6 & 1 & 4,34 \\
\hline
\end{tabular}

Tablo 6. incelendiğinde 9 öğrencinin (Ö7, Ö8, Ö10, Ö11, Ö12, Ö13, Ö16, Ö19, Ö20) anlaşma halkaları yöntemini yeterli bulduğu tespit edilmiştir. Yöntemi yeterli bulduklarını söyleyip nedenini açıklamamışlardır.

14 öğrencinin (Ö1, Ö2, Ö3, Ö4, Ö5, Ö6, Ö9, Ö14, Ö15, Ö17, Ö18, Ö21, Ö22, Ö23) anlaşma halkaları yöntemini yeterli bulmadığı tespit edilmiştir. Bu yöndeki bir öğrenci görüşü aşağıdaki gibidir:

"Anlaşma halkaları eğitim ve öğretimde öğrencinin kendi kendine düşünebilmesini sağlamak ve öğrencinin aktif olarak katılmasını sağlamak amacıyla güzel (öteki türlü uyuyoruz derslerde) çünkü bence bir insan ancak kendi kafasında kendi kendine sorgulayıp bir sonuca vardığı şeyleri uzun süre hatırlayabiliyor. Lakin 30 kişilik halka olmuyor. 15-20 kişi ideal (Ö2)."

"Bence ilgi çekici, konuyla ilgili videolarla desteklenirse daha iyi olur(Ö3)."

"Dersler halka oluşturarak değil de sınıf ortamında tartışma yoluyla anlatılabilir (Ö6)."

"Geliştirilmesi için kullanılan kişi sayısı azaltılabilir. Halkada rekabet unsurları ortaya çıkartılarak dozunda daha keyifli hale gelebilir(Ö9)."

Ö4, Ö21, Ö22 kodlu öğrenciler yöntemi bu haliyle yeterli bulmadıklarını söyleyip nedenini açıklamamışlardır. Öğrencilerin Tahmin et-Gözle-Açıkla yöntemi hakkındaki görüşlerini tespit etmek amacıyla yöneltilen 'Soru 4' için elde edilen bulgular Tablo 7'de sunulmuştur.

Tablo 7. Öğrencilerin TGA Hakkındaki Görüşleriniz Nelerdir? Sorusuna Verdiği Cevaplara Ait Kategori Ve Kodların Frekans Ve Yüzde Değerleri

\begin{tabular}{llrcr}
\hline \hline Kategori & Kod & Öğrenci & Frekans & Yüzde \\
\hline \multirow{2}{*}{ Olumlu } & Öğretici olması & Ö1, Ö2, Ö3, Ö13, Ö14 & 5 & 21,74 \\
& Akılda kalıcı olması & Ö4, Ö16, Ö21, Ö22, Ö23 & 5 & 21,74 \\
& Güzel olması & Ö6, Ö7, Ö8, Ö17, Ö18 & 5 & 21,74
\end{tabular}




\begin{tabular}{llrrr} 
& Öğrenmeyi kolaylaştırması & Ö5, Ö11, Ö19, Ö20 & 4 & 17,39 \\
& Çok faydalı olması & Ö9, Ö10 & 2 & 8,69 \\
Olumsuz & Zaman alııı olması & Ö12, Ö15 & 2 & 8,69 \\
\hline
\end{tabular}

Tablo 7. incelendiğinde 21 öğrencinin (Ö1, Ö2, Ö3, Ö4, Ö5, Ö6, Ö7, Ö8, Ö9, Ö10, Ö11, Ö13, Ö14, Ö16, Ö17, Ö18, Ö19, Ö20, Ö21, Ö22, Ö23 ) TGA yöntemi hakkında olumlu düşüncelere sahip olduğu tespit edilmiştir. Bu yöndeki bazı öğrenci görüşleri aşağıdaki gibidir:

"Bilgilerin aklımda kalmasını sağladı (Ö4)."

"Daha iyi öğrenmemi sağladı (Ö19)."

2 öğrencinin (Ö12, Ö15) TGA yöntemi hakkında olumsuz düşüncelere sahip olduğu tespit edilmiştir. Bu yöndeki bir öğrenci görüşü aşağıdaki gibidir:

"Çok zamanımızı aldı (Ö15).".

\section{Sonuç ve Öneriler}

\section{1. Öğrencilerin Planlı Biçimlendirici Değerlendirme Sorularından Uygulama Öncesi ve Son- rası Elde Ettikleri Sonuçlar}

Bu bölümde öncelikle Tablo 8 ve Tablo 9'da öğrencilerin planlı biçimlendirici değerlendirme sorularına verdikleri cevaplara ait uygulama öncesi ve sonrası kavramsal gelişim ve değişimler gösterilmiştir. Ardından tablolar açıklanmıştır.

Tablo 8. Öğrencilerin Ilk 4 Soru İçin Verdikleri Cevaplara Ait Uygulama Öncesi ve Uygulama Sonrası Kavramsal Değişimleri

\begin{tabular}{lrrrr}
\hline \hline $\begin{array}{l}\text { Uygulama } \\
\text { oncesi-> } \\
\text { Uygulama } \\
\text { sonrası }\end{array}$ & 1.soru için & 2.soru için & 3.soru için & 4.soru için \\
\hline HA->SKY & & & \\
HA->KK & Ö4, Ö5 & Ö8, Ö14, Ö16, Ö22 & Ö8, Ö9, Ö20, \\
SKY->KK & Ö5, Ö15, Ö16, Ö20 & Ö9, Ö16, Ö20, Ö23 & Ö11, Ö19 & Ö16 \\
SKY->TK & & Ö11 & &
\end{tabular}




\begin{tabular}{lrrrr} 
TK->SKY & Ö6, Ö21 & Ö6, Ö21 & \\
KK->SKY & & & Ö6, Ö15 & Ö1, Ö15 \\
SKY->HA & & & Ö13 & Ö7, Ö14, Ö22 \\
Aynı & Ö1, Ö2, Ö3, Ö4, Ö7, Ö8, & Ö1, Ö2, Ö3, & Ö1, Ö2, Ö3, & Ö3, Ö4, Ö5, \\
düzeyde & Ö9, Ö10, Ö11, Ö12, Ö13, & Ö7, Ö8, Ö10, Ö12, & Ö5, Ö9, Ö10, Ö12, & Ö6, Ö10, Ö11, \\
kalanlar & Ö14, Ö17, Ö18, Ö19, & Ö13, Ö14, Ö15, & Ö18, Ö20, Ö21, Ö23 & Ö12, Ö13, \\
& Ö22, Ö23 & Ö17, Ö18, Ö19, Ö22 & & Ö17, Ö18, \\
& & & Ö19, Ö21 \\
\hline
\end{tabular}

Tablo 9. Öğrencilerin Son 4 Soru Iç̧in Verdikleri Cevaplara Ait Uygulama Öncesi Ve Uygulama Sonrası Kavramsal Değişimleri

\begin{tabular}{|c|c|c|c|c|}
\hline Uyqulama & 5.soru icin & 6.soru icin & 7.soru icin & 8.soru için \\
\hline $\mathrm{HA}->\mathrm{SKY}$ & & & Ö15 & Ö1, Ö2, Ö12, Ö15 \\
\hline $\mathrm{HA}->\mathrm{KK}$ & & Ö4, Ö14, Ö15 & Ö4, Ö16 & Ö5, Ö22 \\
\hline $\mathrm{HA}->\mathrm{TK}$ & & Ö8 & & Ö9 \\
\hline SKY->KK & Ö16, Ö20, Ö23 & Ö9, Ö20, Ö23 & Ö14, Ö19, Ö20, Ö22 & Ö6, Ö20, Ö23 \\
\hline SKY->TK & Ö11 & Ö11 & & \\
\hline KK->TK & & & & Ö19 \\
\hline TK->KK & & & Ö21 & Ö21 \\
\hline $\mathrm{KK}->\mathrm{SKY}$ & Ö13, Ö19 & & Ö17 & Ö4, Ö10, Ö17 \\
\hline $\mathrm{KK}->\mathrm{HA}$ & & & Ö7 & \\
\hline$S K Y->H A$ & Ö18 & Ö22 & Ö3, Ö5 & \\
\hline $\begin{array}{l}\text { Aynı } \\
\text { düzeyde } \\
\text { kalanlar }\end{array}$ & $\begin{array}{r}\text { Ö1, Ö2, Ö3, Ö4, Ö5, } \\
\text { Ö6, Ö7, Ö8, Ö9, } \\
\text { Ö10, Ö12, Ö14, } \\
\text { Ö15, Ö17, Ö21, Ö22 }\end{array}$ & $\begin{array}{r}\text { Ö1, Ö2, Ö3, Ö5, Ö6, } \\
\text { Ö7, Ö10, Ö12, Ö13, } \\
\text { Ö16, Ö17, Ö18, } \\
\text { Ö19, Ö21 }\end{array}$ & $\begin{array}{r}\text { Ö1, Ö2, Ö6, Ö8, Ö9, } \\
\text { Ö10, Ö11, Ö12, } \\
\text { Ö13, Ö18, Ö23 }\end{array}$ & $\begin{array}{r}\text { Ö3, Ö7, Ö8, Ö11, } \\
\text { Ö13, Ö14, Ö16, } \\
\text { Ö18 }\end{array}$ \\
\hline
\end{tabular}

Tablo 8. İncelendiğinde 1. Soruda 4 öğrencinin spesifik kavram yanılgısından kısmen kavrama düzeyine; 2 . Soruda 2 öğrencinin hiç anlamama düzeyinden kısmen kavrama düzeyine, 4 öğrencinin spesifik kavram yanılgısından kısmen kavrama düzeyine ve 1 öğrencinin spesifik kavram yanılgısından tam kavrama düzeyine; 3. Soruda 2 öğrencinin spesifik kavram yanılgısından kısmen kavrama düzeyine, 3 öğrencinin hiç anlamama düzeyinden kısmen kavrama düzeyine; 4 . soruda 4 öğrencinin hiç anlamama düzeyinden kısmen kavrama düzeyine, 1 öğrencinin spesifik kavram yanılgısından kısmen kavrama düzeyine yükseldiği tespit edilmiştir. 
Tablo 9. incelendiğinde 5. soruda 3 öğrencinin spesifik kavram yanılgısından kısmen kavrama düzeyine; 6. soruda 1 öğrencinin hiç anlamama düzeyinden tam kavrama düzeyine, 1 öğrencinin spesifik kavram yanılgısından tam kavrama düzeyine, 3 öğrencinin hiç anlamama düzeyinden kısmen kavrama düzeyine, 3 öğrencinin spesifik kavram yanılgısından kısmen kavrama düzeyine; 7. soruda 4 öğrencinin spesifik kavram yanılgısından kısmen kavrama düzeyine, 2 öğrencinin hiç anlamama düzeyinden kısmen kavrama düzeyine; 8 . soruda 3 öğrencinin spesifik kavram yanılgısından kısmen kavrama düzeyine, 2 öğrencinin hiç anlamama düzeyinden kısmen kavrama düzeyine, 1 öğrencinin kısmen kavrama düzeyinden tam kavrama düzeyine, 1 öğrencinin hiç anlamama düzeyinden tam kavrama düzeyine yükseldiği tespit edilmiştir.

İlgili araştırmalar bu bulguyu destekler niteliktedir. Özbaş, Tüdeş, illeri, Duman (2013) tıp öğrencileri ile yaptıkları çalışmada, araştırma sonucunda tıp eğitiminde biçimlendirici değerlendirmenin öğrenme davranışı üzerinde güçlü bir etkiye sahip olduğunu, düzenli çalışmaya ve öğrenci başarısına olumlu etkilerinin olduğunu saptamışlardır. Ozan (2017) 5. sınıf öğrencileri ile yaptığı çalışmada, deney grubunda uygulanan biçimlendirici değerlendirmenin öğrencilerin akademik başarılarını, derse yönelik tutum ve öz düzenleme becerilerini anlamlı ölçüde arttırdığı sonucuna ulaşmıştır.

Aynı kazanımın ölçülmek istendiği 1. ve 5. soru için öğrencilerden istenen tam kavrama düzeyindeki doğru cevap, katıların çözünürlüğü endotermik (ısıalan) olduğundan sıcaklık arttıkça çözünürlük katılarda genellikle artar olmalıydı. Az miktarda bir maddenin, doygunluğa yakın bir çözeltide ısı alarak çözündügünü varsayalım. Çözünen katının aşırısı ile doymuş çözelti arasında aşağıdaki dengeyi yazabiliriz.

$$
\text { Enerji + çözünen }(k)+\mathrm{H}_{2} \mathrm{O}------->\text { doymuş çözelti }
$$

Bir sistem üzerinde sıcaklık değişmesinin etkisi 1884'te Henri Le Chatelier tarafından önerilmiş bir kural yardımıyla irdelenmiştir. Le Chatelier kuralına göre, dengedeki bir sisteme dışarıdan bir etkide bulunulduğunda, sistem bu etkiyi azaltıcı yönde bir denge hali oluşturur. Bir beher içinde, yukarıda açıklanan türde bir miktar katı çözünenle dengede bulunan bir doymuş çözelti bulunduğunu varsayalım. Bu sistemin sıcaklığını yükseltirsek, Le Chatelier kuralına göre sistemin sıcaklığını düşürecek yönde tepki göstermesi gerekir. Yani denge sağa kayarak bu etkiyi karşılar. (Yukarıdaki dengede sağa yani çözünmenin artması yönünde). Bunun anlamı daha fazla maddenin çözünmesidir. Buradan sıcaklığın artmasının çözünürlüğü arttırdığı sonucunu çıkarabiliriz. Suyun sıcaklığı arttıkça şekerin suda çözünürlüğü artar. ( $\mathrm{Li}_{2} \mathrm{SO}_{4}$ gibi bazı katılar hariç).

Aynı kazanımın ölçülmek istendiği 2. ve 6. soru için öğrencilerden istenen tam kavrama düzeyindeki doğru cevap, gazların çözünürlüğü ekzotermik (ısıveren) olduğundan sıcaklık arttıkça çözünürlük azalır olmalıydı. Bütün gazların çözünürlüğü sıcaklık arttıkça azalır. Örneğin ısıtılan gazozdan $\mathrm{CO}_{2}$ kabarcıklarının çıktığı gözle görülebilir. Gazların soğuk sudaki çözünürlüğü, lık sudan daha fazladır. Sıcaklık artışı ekzotermik (ısıveren) reaksiyonlarda çözünürlüğü azaltır. Gazların çözünürlüğü sıcaklık arttıkça azalır. Asitli içeceklerin üzerinde "soğuk içiniz" yazmasının nedeni budur. 
Aynı kazanımın ölçülmek istendiği 3. ve 7. soru için öğrencilerden istenen tam kavrama düzeyindeki doğru cevap, Henry Yasası'na göre gazların çözünürlüğü basınç arttıkça artar olmalıydı. Çözünen gazların basıncı ile çözünürlüğü arasındaki ilişki Henry Yasası ile ortaya konmuştur. Henry Yasası'na göre gazların çözünürlüğü, kısmi basınçlarıyla doğru orantılıdır. Çünkü basınçtaki artış, gaz moleküllerinin çözücünün yüzeyine çarpma hızında artmaya neden olur ve bunun sonucunda da çözünürlük artar. Kolalar, gazozlar ve sodalı sular yüksek basınç altında şişelenmiştir ve kapağı açıldığında şişedeki basınç düşmüş olur. Bu nedenle $\mathrm{CO}_{2}$ gazının çözünürlüğü azalır. Gazların çözünürlükleri artan basınçla artar.

Aynı kazanımın ölçülmek istendiği 4. ve 8. soru için öğrencilerden istenen tam kavrama düzeyindeki doğru cevap, katıların çözünürlüklerinde basıncın etkisinin pek olmadığıydı. Çünkü katı ve sıvıların hacimlerine basınç uygulayarak pratikte bir değişme olmaz.

\section{2. Öğrenciler İle Yapılan Yarı Yapılandırılmış Görüşmeden Elde Edilen Sonuçlar}

Öğrencilerin anlaşma halkaları yöntemini derste uyguladıktan sonra bu çalışmanın onlarda arkadaşları ile herhangi bir fizik, kimya ya da biyoloji konusunu tartışma hevesi uyandırıp uyandırmadığını öğrenmek için yöneltilen 'Soru 1' için elde edilen bulgulardan hareketle öğrencilerin \% 82,61 'inin anlaşma halkaları yöntemi derste uygulandıktan sonra bu çalışmanın onlarda arkadaşları ile herhangi bir fizik, kimya ya da biyoloji konusunu tartışma hevesi uyandırdığı tespit edilmiştir.

Anlaşma halkaları yönteminin öğrencilerin ilgisini çekip çekmediğini öğrenmek ve diğer kimya derslerinde ya da farklı disiplinlerde (fizik, biyoloji vs.) uygulanmasını isteyip istemediklerini tespit etmek amacıyla yöneltilen 'Soru 2' için elde edilen bulgulardan hareketle öğrencilerin tamamının anlaşma halkaları yönteminin ilgilerini çektiği, diğer kimya derslerinde ya da farklı disiplinlerde uygulanmasını istedikleri tespit edilmiştir. Buradan öğrencilerin çok büyük bir çoğunluğunun anlaşma halkaları yöntemini beğendikleri ve farklı disiplinlerde uygulanmasının uygun olacağı sonucuna ulaşılabilir. İlgili araştırmalar bu bulguyu destekler niteliktedir. Buldur (2014) yaptığı çalışmada elde ettiği bulgular deney grubundaki öğrencilerin çok büyük bir kısmının deneysel işlem sürecindeki değerlendirme anlayışı hakkında olumlu görüşlere sahip olduklarını ve gelecekteki fen bilimleri derslerinde de benzer şekilde değerlendirilmek istediklerini göstermiştir. Choi, Nam ve Lee (2001) 7. sınıf öğrencileri ile yaptıkları çalışmada, sonuçlar ayrıntılı ve destekleyici geribildirimlerle biçimlendirici değerlendirmelerin kullanılmasının öğrencilerin ilgisini artırmada, konudaki güveni arttırmada, katılımlarını arttırmada ve kaygılarını azaltmada daha etkili olduğunu göstermiştir.

Öğrencilerin anlaşma halkaları yöntemini bu haliyle yeterli bulup bulmadığını, yeterli bulmuyor iseler geliştirilmesi için önerilerinin neler olduğunu tespit etmek amacıyla yöneltilen 'Soru 3' için elde edilen bulgulardan hareketle öğrencilerin \% 39,13'ünün anlaşma halkaları yöntemini yeterli bulduğu tespit edilmiştir. Buradan yöntemin geliştirilebileceğini savunabiliriz. Yöntem, bu konu için öğrencilerin de talep ettiği şekilde çeşitli videolar ve somut materyaller ile desteklenebilir.

Öğrencilerin Tahmin et- Gözle- Açıkla yöntemi hakkındaki görüşlerini tespit etmek amacıyla yöneltilen 'Soru 4' için elde edilen bulgulardan hareketle öğrencilerin \% 91,31'inin yöntem hakkında 
olumlu düşüncelere sahip olduğu saptanmıştır. Dersin işlenişi sırasındaki gözlemlerden de yola çıkarak Tahmin et- Gözle- Açıkla yönteminin öğrencilerin motivasyonunu arttırmasından ve uygulanmasının kolay olması gibi sebeplerden dolayı öğrenciler tarafından beğenildiği sonucuna varılabilir. İlgili araştırmalar bu bulguyu destekler niteliktedir. TGA yöntemi, öğrencilerin kavram yanılgılarını açığa çıkaran, anlamlı öğrenmeyi gerçekleştirmeye katkıda bulunan, öğrencilerin motivasyonunu artıran ve uygulanması kolay etkili bir öğretim yöntemidir (Altınok, 2017; Bilen, 2009; Köse Bilen ve Uçak, 2010). Altınok (2017) yaptığı çalışmada sonuçlar fen bilgisi öğretmen adaylarının TGA yöntemi ile ilgili olumlu düşüncelere sahip olduğunu göstermiştir.

\section{3. Öneriler}

12. sınıf öğrencileri ile gerçekleştirilen derslerde öğrencilerin çok büyük çoğunluğunun derse ilgi gösterdiği, aktif katııım sağladıkları ve öğrencilerin merakının oldukça yüksek olduğu gözlenmiştir. Yalnız 12. sınıfların ara ara sınav kaygılarının olduklarını belirttikleri gözlenmiştir. Biçimlendirici değerlendirme yaklaşımının kimya dersinde ve diğer disiplinlerde de uygulanarak öğrencilerin derse aktif katılan ve sorgulayan öğrenciler olmaları sağlanabilir. Günümüzdeki eğitim sistemiyle öğrenciler sürekli test yöntemine maruz kaldıklarından kendilerini ifade etmekte oldukça zorluk çekmektedirler. Hatta bu tarz sorulara alışık olmadıkları için soruları ellerinde görmek isteyen öğrenciler olmuştur. Dinleyerek bir ifadeyi anlamakta güçlük çektiklerinden dolayı ifadeler birkaç kez öğrencilere tekrarlanmıştır. Biçimlendirici değerlendirme uygulamaları ile öğrencilerin birbirleriyle ve öğretmenleriyle sürekli iletişim halinde olarak kendilerini ifade etme yeteneklerinin de güçlenmesi sağlanabilir. Öğrencilerin kimya derslerine ilgilerinin artması için ve özellikle yanlış ve eksik öğrenmelerinin saptanıp dersin bu saptamalara göre planlanması ve dersin gidişatının belirlenmesi için biçimlendirici değerlendirme yaklaşımının diğer kimya konularında ve fizik, biyoloji gibi diğer disiplinlerde de kullanılması önerilmektedir. Biçimlendirici değerlendirme yönteminin hizmet içi eğitim kurslarıyla öğretmenlere ve ilgili dersler kapsamında üniversitelerin eğitim fakültelerinde okuyan öğretmen adaylarına tanıtılmasının fayda sağlayacağı düşünülmektedir. Daha fazla biçimlendirici değerlendirme uygulamalarıyla öğrenciler soru sormaya teşvik edilerek deney ve gözlem yapmaları sağlanarak öğrencilerin tamamına yakınının bu derslere ilgi duymaları ve bu yönde çalışmalar yapmaları sağlanabilir.

\section{Teşekkür}

Doç. Dr. Mızrap BULUNUZ’a planlı biçimlendirici değerlendirme sorusunu hazırlamamızda bize yardımcı olduğu için kendisine teşekkür ederiz.

\section{Kaynaklar}

Altınok, O. (2017). TGA tekniğine dayalı laboratuvar etkinliklerinin fen bilgisi öğretmen adaylarının argüman oluşturma becerilerine etkisinin incelenmesi. Yüksek Lisans Tezi. Recep Tayyip Erdoğan Üniversitesi, Rize. 
Bilen, K. (2009). Tahmin et-gözle-açıkla yöntemine dayalı lâboratuar uygulamalarının öğretmen adaylarının kavramsal başarılarına, bilimsel süreç becerilerine, tutumlarına ve bilimin doğası hakkındaki görüşlerine etkisi. Doktora tezi (basılmamış). Gazi Üniversitesi, 169s, Ankara.

Bell, B. \& Cowie, B. (2000). The Characteristics of Formative Assessment in Science Education. 2001John Wiley \& Sons, Inc. Pp. 536-553. Retrieved September 13, 2012 from http://onlinelibrary.wiley.com/doi/10.1002/sce.1022/

Bennett, R.E. (2011). Formative assessment: A critical review. Assessment in Education: Principles, Policy \& Practice, 18(1), 5-25. http://dx.doi.org/10.1080/0969594X.2010.513678

Black, P. (1996). Formative assessment and the improvement of learning. British Journal of Special Education, 23(2), 51-56.

Boston, C. (2002). The concept of formative assessment. Eric Digest, 8, 101- 105.

Bourgeois, S.P., Dutura, A.A., Mccrohan, H.D., Riviere P.E., Smith, H.E., Souza, R., \& Pariser, E.R. (1986). Experimenting with water: factors affecting the solubility of substances in water. Journal of Marine Education, 7(1), 15-50.

Buldur, S. (2014). Performansa dayalı tekniklerle yürütülen biçimlendirmeye yönelik değerlendirme sürecinin öğretmen ve öğrenci üzerindeki etkisi (Yayımlanmamış doktora tezi). Gazi Üniversitesi, Ankara.

Bulunuz, M., ve Bulunuz, N. (2013). Fen öğretiminde biçimlendirici değerlendirme ve etkili uygulama örneklerinin tanıtılması. Türk Fen Eğitimi Dergisi, 10(4), 119- 135.

Bulunuz, M., ve Bulunuz, N. (2014). Fen öğretiminde biçimlendirici değerlendirme ve etkili uygulama örneklerinin tanıtılması II. Yeni Türkiye Dergisi, 59, 1278-1283.

Bulunuz, M., ve Bulunuz, N. (2016). Biçimlendirici değerlendirme sorusu kullanılarak lise öğrencilerine eylemsizlikle ilgili yapılan öğretimin değerlendirilmesi. Araştırma Temelli Etkinlik Dergisi, (ATED), 6(2), 50-62.

Bulunuz, N., Bulunuz, M., ve Peker, H. (2014). Effects of formative assessment probes integrated in extra-curricular hands-on science: Middle school students'understanding. Journal of Baltic Science Education, 13(2), 243-258.

Choi, K., Nam, J. H., \& Lee, H. (2001). The effects of formative assessment with detailed feedback on students' science learning achievement and attitudes regarding formative assessment. Science Educational International, 12(2), 28-34.

Cooper-Twamley, S.M., (2009). Action research and its effects on teacher efficacy: A Mixed Methods Case Study. M.E. Thesis. Submitted to the Graduate Faculty of Baylor University in Partial Fulfillment of the Requirements for the Degree of Doctor of Education 
Coştu, B., Ayas, A., Açıkkar, E. ve Çalık, M. (2007). Çözünürlük konusu ile ilgili kavramlar ne düzeyde anlaşılıyor?. Boğaziçi Üniversitesi Eğitim Dergisi, 24 (2), 13-28.

Cowie, B. \& Bell, B. (1999). A model of formative assessment in science education. Assessment in Education, 6(1), 101-116. doi:10.1080/09695949993026

Fluckiger, J., Tixier, Y.T., Pasco, R., \& Danielson, K. (2010). Formative feedback: Involving students as partners in assessment to enhance learning. College Teaching, 58(4), 136-140.

Furtak, E. M., Ruiz Primo, M. A., Shemwell, J. T., Ayala, C. C., Brandon, P. R., Shavelson, R. J., \& Yin, Y. (2008). On the fidelity of implementing embedded formative assessments and its relation to student learning. Applied Measurement in Education, 21, 360-389. http://dx.doi.org/10.1080/08957340802347852

Karataş, F.Ö., Köse, S. ve Coştu, B. (2003). Öğrenci yanılgılarını ve anlama düzeylerini belirlemede kullanılan iki aşamalı testler. Pamukkale Üniversitesi Eğitim Fakültesi Dergisi, 1 (13), 54.

Keeley, P. (2008). Science formative assessment: 75 practical strategies for linking assessment, instruction, and learning. California: Corwin ve NSTA Press.

Keeley, P. \& Harrington, R. (2014). Vol.2 Uncovering student ideas in physical science 39 new electricity and magnetism formative assessment probes. Arlington, Virginia: NSTA Press.

Köse, S., Bilen, K. ve Uçak, E. (2010). Predict-observe-explain (POE) strategy as a diagnostic tool to determine pre-service primary teachers' misconception on food synthesis of plants and photosynthesis. Proceedings of the 6th International Conference on Education, JULY 8-10, Samos Island, Greece, 96-105.

Milli Eğitim Bakanlığı (MEB) (2018). Ortaöğretim Kimya Dersi (9, 10, 11 ve 12. sınıflar) Öğretim Programı, Ankara: MEB Yayınevi.

Özbaş, G. Tüdeş, T., İleri, E., ve Duman, M. (2013). Formatif Değerlendirmenin Öğrenme Sürecine Etkisinin Belirlenmesi, 28 Ağustos 2018 tarihinde https://docplayer.biz.tr/17885878-Formatifdegerlendirmenin-ogrenme-surecine-etkisinin-belirlenmesi.html adresinden ulaşılmıştır.

Stull, J.C., Varnum, S.C., Ducette J., Schiller, J., \& Bernacki, M. (2011). The many faces of formative assessment. International Journal of Teaching and Learning in Higher Education, 23 (1), 30-39.

Şahin, Ç. ve Çepni, S. (2011). Yüzme-batma, kaldırma kuvveti ve basınç kavramları ile ilgili iki aşamalı kavramsal yapılardaki farklılaşmayı belirleme testi geliştirilmesi. Türk Fen Eğitimi Dergisi, 8 (1), 79-110.

Tezcan, H., and Bilgin, E. (2004). Liselerde çözünürlük konusunun öğretiminde laboratuvar yönteminin ve bazı faktörlerin öğrenci başarısına etkileri. GÜ Gazi Eğitim Fakültesi Dergisi, 24, (3), 175-191. 
White, R., \& Gunstone, R. (1992). Probing Understanding. The Falmer Press. London and New York.

Yalaki, Y. (2010). Simple formative assessment high learning gains in college general chemistry. Eurasian Journal of Educational Research, 40, 223-241.

Yıldırım, A. ve Şimşek A.(2013). Sosyal Bilimlerde Nitel Araştırma Yöntemleri: Seçkin Yayıncılık.

Yuladır, C. ve Doğan, S. (2009). Eylem araştırmasının eğitimde kullanımı. Ekev Akademi Dergisi, 13, 105- 122.

\section{EK-1}

Planlı Biçimlendirici Değerlendirme Soruları

Çözünürlüğü etkileyen faktörler ile ilgili olarak aşağıdaki ifadelerden size göre doğru olanlara + işareti koyunuz.

\begin{tabular}{|l|l|}
\hline Şekerin suda çözünürlüğü sıcaklık arttıkça artar. \\
$\mathrm{CO}_{2}^{\prime}$ in soda içindeki çözünürlüğü sıcaklık arttıkça artar. \\
Basıncın düşmesi gazların sıvılardaki çözünürlüğünü azaltır. \\
Basıncın değişmesi katı ve sıvıların çözünürlüğünü pek etkilemez. \\
Suyun sıcaklığı arttıkça şekerin suda çözünürlüğü artar. \\
Gazların soğuk sudaki çözünürlüğü, ılık sudan daha fazladır. \\
Kolanın kapağı açılırsa, içindeki $\mathrm{CO}_{2}^{\prime}$ nin çözünürlüğü artar.
\end{tabular}




\begin{tabular}{|l|l|}
\hline & Basınç arttırılarak kola içinde çözünen şeker miktarı arttırılabilir. \\
\hline
\end{tabular}

\section{EK-2}

\section{Tahmin Et-Gözle-Açıkla Yönteminin Uygulanışı}

Tahmin aşaması: Öğrenciler tahminlerini kendilerine dağıtılan biçimlendirici değerlendirme soru kağıtlarına yazarlar.

Gözlem aşaması: Öğrenciler bu aşamada gözlem yaparlar. 1 su bardağına $250 \mathrm{ml}$ soğuk su dökülür. Ardından 1 küp şeker ilave edilerek şekerin soğuk suda çözünmesi gözlemlenir. Bu işlemin ardından 1 su bardağına $250 \mathrm{ml}$ sıcak su dökülür. Ardından 1 küp şeker ilave edilerek şekerin sıcak suda çözünmesi gözlemlenir. Buradan şekerin suda çözünürlüğünün sıcaklık arttıkça arttığı sonucuna ulaşılır. Daha sonra asitli içeceğin üzerinde yazan "soğuk içiniz" ibaresi ve içindekiler kısmı öğrencilere okutulur. Buradan $\mathrm{CO}_{2}$ 'in soda içindeki çözünürlüğünün sıcaklık arttıkça azalacağı sonucuna ulaşılır. Ardından asitli içeceğin kapağı açılır. $\mathrm{CO}_{2}$ çıkışı gözlemlenir. Buradan basıncın düşmesinin gazların sıvılardaki çözünürlüğünü azalttığı sonucuna ulaşılır. En son olarak bir pet şişenin içine sıcak bir tuzlu su çözeltisi dökerek şişenin tüm kısmının bu sıcak sudan etkilenmesi sağlanır. Böylece içerideki hava ısınıp gaz taneciklerinin hareketi artar ve içerideki gaz basıncı artmış olur. Bu sırada çözünen tuz miktarı gözlemlenir. Daha sonra pet şişenin ağzını kapattığımız zaman pet şişe içinde basınç azalmış olur. Basınç azalınca çözünen tuz miktarı tekrar gözlemlenir ve buradan basıncın değişmesinin katı basıncını pek etkilemediği gözlemlenir. Buradan basıncın değişmesinin katı çözünürlüğünü pek etkilemediği sonucuna ulaşılır.

\section{Açıklama aşaması:}

Yaptığımız 1. etkinlikte şekerin suda çözünürlüğünün sıcaklık arttıkça arttığını gözlemledik. Şeker katı bir maddedir. Katıların çözünürlüğü endotermik (ısı alan) olduğundan sıcaklık arttıkça çözünürlük artar. ( $\mathrm{Li}_{2} \mathrm{SO}_{4}$ gibi bazı katılar hariç).

Yaptığımız 2. etkinlikte $\mathrm{CO}_{2}$ 'in soda içindeki çözünürlüğünün sıcaklık arttıkça azaldığını gözlemledik. Gazoz gibi asitli içeceklerin içindeki gazlar soğuk ortamda daha iyi çözündüğü için asitli içeceklerin üstünde soğuk içiniz yazar. Gazların çözünürlüğü ekzotermik (ısı veren) olduğundan sıcaklık arttıkça gazların çözünürlüğü azalır. 
Yaptığımız 3.etkinlikte gazoz şişesinin kapağını açınca $\mathrm{CO}_{2}$ çıkışından kaynaklanan gaz kabarcıklarını gözlemledik ve sesini işittik. Kolalar, gazozlar ve sodalı sular yüksek basınç altında şişelenmiştir ve kapağı açtığımızda şişedeki basıncı düşürmüş olduk. Bu nedenle $\mathrm{CO}_{2}$ gazının çözünürlüğü azaldı. Gazların çözünürlükleri artan basınçla artar. Gazlı içeceklerin yüksek basınç altında şişelenmesi buna örnektir. Şişe açıldığı zaman içecek, $\mathrm{CO}_{2}$ kaybeder. Çözünen gazların basıncı ile çözünürlüğü arasındaki ilişki Henry Yasası ile ortaya konmuştur. Henry Yasası'na göre gazların çözünürlüğü, kısmi basınçlarıyla doğru orantılıdır. Çünkü basınçtaki artış, gaz moleküllerinin çözücünün yüzeyine çarpma hızında artmaya neden olur ve bunun sonucunda da çözünürlük artar.

Yaptığımız 4.etkinlikte pet şişenin ağzını kapattığımızda basıncın değişmesiyle katı madde olan tuzun sıvı madde olan suda çözünürlüğünün pek değişmediğini gözlemledik. Katı maddelerin çözünürlüklerine basıncın etkisinin çok az olduğunu söyleyebiliriz. Sıvı maddelerin çözünürlüklerine de basıncın etkisi çok azdır.

\section{Anlaşma halkasında kullanılan bazı sorular aşağıda verilmiştir:}

1) Katıların çözünürlüğü endotermik (ISı alan) olduğundan sıcaklık arttıkça çözünürlük artar. (D ) Az miktarda bir maddenin, doygunluğa yakın bir çözeltide ısı alarak çözündüğünü varsayalım. Çözünen katının aşırısı ile doymuş çözelti arasında aşağıdaki dengeyi yazabiliriz.

Enerji + çözünen katı $+\mathrm{H}_{2} \mathrm{O} \rightarrow$ doymuş çözelti

Bir sistem üzerinde sıcaklık değişmesinin etkisi 1884'te Heni Le Chatelier tarafından önerilmiş bir kural yardımıyla irdelenmiştir. Le Chatelier kuralına göre, dengedeki bir sisteme dışarıdan bir etkide bulunulduğunda, sistem bu etkiyi azaltıcı yönde bir denge hali oluşturur. Bir beher içinde, yukarıda açıklanan türde bir miktar katı çözünenle dengede bulunan bir doymuş çözelti bulunduğunu varsayalım. Bu sistemin sıcaklı̆ını yükseltirsek, Le Chatelier kuralına göre sistemin sıcaklığını düşürecek yönde tepki göstermesi gerekir. Yani denge sağa kayarak bu etkiyi karşılar. (Yukarıdaki dengede sağa yani çözünmenin artması yönünde). Bunun anlamı daha fazla maddenin çözünmesidir. Buradan sıcaklığın artmasının çözünürlüğü arttırdığı sonucunu çıkarabiliriz. Örneğin suyun sıcaklığı arttıkça şekerin suda çözünürlüğü artar. (Li2 $\mathrm{SO}_{4}$ gibi bazı katılar hariç).

2) Gazların çözünürlüğü endotermik (ıSı alan) olduğundan sıcaklık arttıkça çözünürlük artar. ( Y ) Bütün gazların çözünürlüğü sıcaklık arttıkça azalır. Örneğin ısıtılan gazozdan $\mathrm{CO}_{2}$ kabarcıklarının çıktığı gözle görülebilir. Gazların soğuk sudaki çözünürlüğü, ıık sudan daha fazladır. Sıcaklık artışı ekzotermik (ısı veren) reaksiyonlarda çözünürlüğü azaltır. Gazların çözünürlüğü sıcaklık arttıkça azalır. Asitli içeceklerin üzerinde "soğuk içiniz" yazmasının nedeni budur.

3) Basınç azaldıkça gazların sudaki çözünürlüğü $\operatorname{artar.~(~Y~)~}$ 
Çözünen gazların basıncı ile çözünürlüğü arasındaki ilişki Henry Yasası ile ortaya konmuştur. Henry Yasası'na göre gazların çözünürlüğü, kısmi basınçlarıyla doğru orantılıdır. Çünkü basınçtaki artış, gaz moleküllerinin çözücünün yüzeyine çarpma hızında artmaya neden olur ve bunun sonucunda da çözünürlük artar. Kolalar, gazozlar ve sodalı sular yüksek basınç altında şişelenmiştir ve kapağı açıldığında şişedeki basınç düşmüş olur. Bu nedenle $\mathrm{CO}_{2}$ gazının çözünürlüğü azalır. Gazların çözünürlükleri artan basınçla artar.

4) Katıların ve sıvıların çözünürlüklerinde basıncın etkisi yüksektir. ( Y)

Katıların ve sıvıların çözünürlüklerinde basıncın etkisi pek azdır.

5) Dalgıçların vurgun yemesi gazların çözünürlüğünün basınç artmasıyla artmasından kaynaklanmaktadır.(D)

Bir dalgıç derine daldığında, üzerine etkiyen basınç artacağından soluduğu havadaki azot gazı kanda daha çok çözünür. Dalgıç hızla yukarı çıkarsa üzerine etkiyen basınç azalacağından kanında çözünmüş azot, hızla kanı terk eder ve gaz hâline geçer. Damarlarda kabarcıklar oluşturan azot gazı kan dolaşımını engeller ve vurgun olayı meydana gelir.

6) Denizin diplerinde balık türü ve sayısının daha çok olmasının sebebi gazların yüksek basınçta daha fazla çözünmesidir. ( D )

Balıklar suda çözünmüş olarak bulunan oksijeni alır. Oksijen gazı yüksek basınç altında yani diplerdeki suda daha çok çözünür. Bu nedenle denizin diplerinde balık türü ve sayısı daha çoktur.

1) Katıların çözünürlüğü endotermik (ıSı alan) olduğundan sıcaklık arttıkça çözünürlük artar. (D)

Az miktarda bir maddenin, doygunluğa yakın bir çözeltide ısı alarak çözündüğünü varsayalım. Çözünen katının aşırısı ile doymuş çözelti arasında aşağıdaki dengeyi yazabiliriz.

Enerji + çözünen katı $+\mathrm{H}_{2} \mathrm{O} \rightarrow$ doymuş çözelti

Bir sistem üzerinde sıcaklık değişmesinin etkisi 1884 'te Heni Le Chatelier tarafından önerilmiş bir kural yardımıyla irdelenmiştir. Le Chatelier kuralına göre, dengedeki bir sisteme dışarıdan bir etkide bulunulduğunda, sistem bu etkiyi azaltıcı yönde bir denge hali oluşturur. Bir beher içinde, yukarıda açıklanan türde bir miktar katı çözünenle dengede bulunan bir doymuş çözelti bulunduğunu varsayalım. Bu sistemin sıcaklığını yükseltirsek, Le Chatelier kuralına göre sistemin sıcaklığını düşürecek yönde tepki göstermesi gerekir. Yani denge 
sağa kayarak bu etkiyi karşılar. (Yukarıdaki dengede sağa yani çözünmenin artması yönünde). Bunun anlamı daha fazla maddenin çözünmesidir. Buradan sıcaklığın artmasının çözünürlüğü arttırdığı sonucunu çıkarabiliriz. Örneğin suyun sıcaklığı arttıkça şekerin suda çözünürlüğü artar. ( $\mathrm{Li}_{2} \mathrm{SO}_{4}$ gibi bazı katılar hariç).

2) Gazların çözünürlüğü endotermik (ıSı alan) olduğundan sıcaklık arttıkça çözünürlük artar. ( $\mathrm{Y}$ )

Bütün gazların çözünürlüğü sıcaklık arttıkça azalır. Örneğin ısıtılan gazozdan $\mathrm{CO}_{2}$ kabarcıklarının çıktığı gözle görülebilir. Gazların soğuk sudaki çözünürlüğü, ılık sudan daha fazladır. Sıcaklık artışı ekzotermik (ıSı veren) reaksiyonlarda çözünürlüğü azaltır. Gazların çözünürlüğü sıcaklık arttıkça azalır. Asitli içeceklerin üzerinde "soğuk içiniz" yazmasının nedeni budur.

3) Basınç azaldıkça gazların sudaki çözünürlüğü artar. ( Y )

Çözünen gazların basıncı ile çözünürlüğü arasındaki ilişki Henry Yasası ile ortaya konmuştur. Henry Yasası'na göre gazların çözünürlüğü, kısmi basınçlarıyla doğru orantılıdır. Çünkü basınçtaki artış, gaz moleküllerinin çözücünün yüzeyine çarpma hızında artmaya neden olur ve bunun sonucunda da çözünürlük artar. Kolalar, gazozlar ve sodalı sular yüksek basınç altında şişelenmiştir ve kapağı açıldığında şişedeki basınç düşmüş olur. Bu nedenle $\mathrm{CO}_{2}$ gazının çözünürlüğü azalır. Gazların çözünürlükleri artan basınçla artar. 4) Katıların ve sıvıların çözünürlüklerinde basıncın etkisi yüksektir. ( Y)

Katıların ve sıvıların çözünürlüklerinde basıncın etkisi pek azdır.

5) Dalgıçların vurgun yemesi gazların çözünürlüğünün basınç artmasıyla artmasından kaynaklanmaktadır.(D)

Bir dalgıç derine daldığında, üzerine etkiyen basınç artacağından soluduğu havadaki azot gazı kanda daha çok çözünür. Dalgıç hızla yukarı çıkarsa üzerine etkiyen basınç azalacağından kanında çözünmüş azot, hızla kanı terk eder ve gaz hâline geçer. Damarlarda kabarcıklar oluşturan azot gazı kan dolaşımını engeller ve vurgun olayı meydana gelir.

6) Denizin diplerinde balık türü ve sayısının daha çok olmasının sebebi gazların yüksek basınçta daha fazla çözünmesidir. ( D )

Balıklar suda çözünmüş olarak bulunan oksijeni alır. Oksijen gazı yüksek basınç altında yani diplerdeki suda daha çok çözünür. Bu nedenle denizin diplerinde balık türü ve sayısı daha çoktur. 
Pınar RUSÇUKLU | Zehra ÖZDiLEK 